\title{
EFFECT OF SERVICE QUALITY ON CONSUMER DECISIONS PAYING ELECTRIC ACCOUNT IN MANADO INDONESIA
}

\author{
Johana. M. Ratag, Kiet Tumiwa, Selvie. J. Nangoy, Harty U.H.L. Koagouw, Grace Ropa \\ Department of Accounting, Polytechnic of Manado Country \\ DOI: $10.31364 / S C I R J / v 6 . i 10.2018 . P 1018571$ \\ http://dx.doi.org/10.31364/SCIRJ/v6.i10.2018.P1018571
}

\begin{abstract}
The purpose of this research was to determine the effect of service quality both simultaneously and partially on the decision of consumers to pay electricity bills at the PPOB counter, and to find out the dimensions that most influence the decision of consumers to pay electricity bills at the PPOB counter. The type of research used in this study is causal quantitative research. The method used in collecting data, namely: Literature study, field study. In this study the subject, namely all customers who pay bills, or electricity accounts at payment counters, especially in PPOB. The number of samples or respondents in this study were as many as 60 respondents obtained from the formula $10 \times \mathrm{n}$ (where $\mathrm{n}=$ the number of variables in the study both independent and dependent variables). Multiple linear regression analysis model which is used to test hypotheses. The results showed that the dimensions of service quality, proved to have a positive influence on the decision, paying consumer electricity accounts at PPOB in Manado. Dimension of reliability, proved to have a positive influence on the decision, pay electricity bills.Dimensions of responsiveness, proved to have a positive influence on the decision to pay electricity bills. The dimensions of collateral, proved to have a positive influence on the decision to pay electricity bills. The dimension of empathy, proved to have the greatest influence on the decision to pay electricity bills. This can be seen in the table of classical assumption test results, and multiple linear analysis in the table of coefficients, where the standardized coefficients in beta are 27\%. Simultaneously, or together, the dimensions of service quality which consist of direct evidence, reliability, responsiveness, assurance, and empathy have different effects on the decision to pay consumer electricity bills at PPOB in Manado.
\end{abstract}

Keywords : Service Quality, Decision, Paying electricity.

\section{INTRODUCTION}

The State Electricity Company (Persero) is a state-owned enterprise, which is engaged in electricity in Indonesia. The State Electricity Company has the task of managing transmission, operating systems and transactions of electricity, with worldclass quality services that are capable of meeting stakeholder expectations, and contributing to the improvement of community welfare. Therefore, the State Electricity Company must be able to provide the best service to people from remote villages to big cities. Service is a very important element in the effort to increase customer satisfaction. Basically this service position is a supporting factor in the marketing activities of the State Electricity Company services. In order to improve electricity supply services by the State Electricity Company Limited Company to the public in general and customers in particular, then based on the instruction of the Minister of Mines and Energy Number: 1800/09 / M.DJL / 89 dated May 25, 1989, instructing all levels State Electricity Company, to implement measures to increase efficiency, quality of service and reliability of electricity supply. For this reason, the State Electricity Company gives special attention to service activities in terms of meeting customer needs, so that in its implementation it can satisfy its customers.

The object in this study is the Manado State Electricity Company, especially the electricity bill payment counter at PPOB counters, or Payment Point Online Banking (PPOB). The development of these counters was caused by the State Electricity Company having taken a policy, to transfer previous electricity bill payments, carried out at branch offices throughout Indonesia to third parties, namely through PPOB. This is expected to streamline and streamline payments from consumers, and it is hoped that the State Electricity Company will only focus on adding networks, and maintaining networks. The development of an online electricity payment system has an impact on the community, where they can pay electricity bills at counters located anywhere. The ease of opening a PPOB counter, also causes it to grow rapidly throughout Indonesia, even to remote areas where people who are interested, or who wish to open this counter, can open it with small capital, starting from 500 thousand rupiahs, this benefits consumers who can pay electricity bills anywhere, because of the large number of counters that appear in residential areas.

Problems from the number of these counters, where services, especially quality services, where due to the ease of establishment of these counters, have the effect of not selecting prospective PPOB counters, who are committed to providing quality services. This also affects consumers where consumers in the long run, will pay their electricity bills that provide excellent service, or quality services. Based on the background, and phenomena that have been described previously, this study takes the title: "Effect of Service Quality on Consumer Decisions Paying Electric Account In Manado Indonesia" 


\section{RESEARCH METHODS}

The type of research used is quantitative causal. Causal quantitative research is the research of a scientific approach to managerial, and economic decision making in a company. The aim is to obtain evidence of a causal relationship, or the influence of the research variables. The location of the study is at the PPOB Counter in Malalayang Manado. This counter is devoted to being an official partner of the State Electricity Company, to pay electricity bills. Data collection methods, namely: Library studies, and field studies. In this study, the subject is all customers who pay bills, or electricity accounts at payment counters, especially in PPOB. The sample is part of the number, and characteristics of the population. If the population is large, and researchers cannot study everything in the population, then researchers can use samples taken from that population. Samples taken from the population must be truly representative, so that the results of the research that can be concluded, can be applied to the population (Sugiyono, 2008). The number of samples, or respondents in this study were as many as 60 respondents, obtained from the formula $10 \mathrm{x} \mathrm{n}$ (where $\mathrm{n}=$ the number of variables in the study both independent variables and the dependent variable). Where according to Sugioyono (2010) one of the criteria for determining the number, if the study uses multivariate analysis (correlation or multiple regression, the number of sample members is 10 times, from the number of variables studied. The number of independent variables in this study are 5 variables, and the dependent variable as many as 1 variable. a total of 6 variables multiplied by $10=60$ respondents.

The multiple linear regression analysis model used to test hypotheses is as follows

Information:

$$
Y=b_{0}+\beta_{1} X_{1}+\beta_{2} X_{2}+\beta_{3} X_{3}+\beta_{4} X_{4}+\beta_{5} X_{5}+\varepsilon_{t}
$$

$\begin{array}{lll}\mathrm{b}_{0} & = & \text { Constants } \\ \beta_{1} & = & \text { Regression coefficient for } \mathrm{X}_{1} \\ \beta_{2} & = & \text { Regression coefficient for } \mathrm{X}_{2} \\ \beta_{3} & = & \text { Regression coefficient for } \mathrm{X}_{3} \\ \beta_{4} & = & \text { Regression coefficient for } \mathrm{X}_{4} \\ \beta_{5} & = & \text { Regression coefficient for } \mathrm{X}_{5} \\ \varepsilon & = & \text { Standard error } \\ \mathrm{Y} & = & \text { Paying decision } \\ \mathrm{X}_{1} & = & \text { Direct evidence } \\ \mathrm{X}_{2} & = & \text { Reliability } \\ \mathrm{X}_{3} & = & \text { Responsiveness } \\ \mathrm{X}_{4} & = & \text { Guarantee } \\ \mathrm{X}_{5} & = & \text { Empathy }\end{array}$

\section{DISCUSSION}

\subsection{Description of Respondents}

Table 1. Amount of Respondents by Gender

\begin{tabular}{llcc}
\hline Number. & Gender & Frequency (N) & Percent (\%) \\
\hline & & & \\
\hline 1. & Man & 29 & 48,3 \\
2. & Woman & 31 & 51,7 \\
\hline & Total & $\mathbf{6 0}$ & $\mathbf{1 0 0}$ \\
\hline
\end{tabular}

Table 2. Amount of Respondents by Age

\begin{tabular}{llcc}
\hline Number. & Age (Year) & Frequency $(\mathbf{N})$ & Percent (\%) \\
\hline & & & \\
\hline 1. & $<18$ & 5 & 8,3 \\
2. & $18-20$ & 8 & 13,3 \\
3. & $21-30$ & 8 & 13,3 \\
4. & $31-40$ & 26 & 43,3 \\
5. & $41-50$ & 9 & 15 \\
6. & $>50$ & 4 & 6,7 \\
\hline & Total & $\mathbf{6 0}$ & $\mathbf{1 0 0}$ \\
\hline
\end{tabular}

Table 3. Amount of Respondents Based on Education Level

\begin{tabular}{llll}
\hline Number. & Last education & Frequency $(\mathrm{N})$ & Percent $(\%)$ \\
\hline
\end{tabular}




\begin{tabular}{llcc}
\hline & & & \\
\hline 1. & Primary school & 1 & 1,7 \\
2. & Junior high school & 5 & 8,3 \\
3. & High School / Vocational High School & 31 & 51,7 \\
4. & Diploma / Strata 1 & 23 & 38,3 \\
\hline & Total & $\mathbf{6 0}$ & $\mathbf{1 0 0}$ \\
\hline
\end{tabular}

Table 4. Amount of Respondents by Job

\begin{tabular}{llcc}
\hline Number. & Work & Frequency (N) & Percent (\%) \\
\hline & & & \\
\hline 1. & Student & 7 & 11,7 \\
2. & Civil Servants / Indonesian National Army / & 6 & 10 \\
& Republic of Indonesia Police & & \\
3. & Retired & 2 & 3,3 \\
5. & Private employees & 18 & 30 \\
6. & Housewife & 14 & 23,3 \\
7. & Does not work & 1 & 1,7 \\
8. & Others & 7 & 11,7 \\
\hline & Total & $\mathbf{6 0}$ & $\mathbf{1 0 0}$ \\
\hline
\end{tabular}

Table 5. Amount of Respondents Based on Income Per Month

\begin{tabular}{llcc}
\hline Number. & Monthly Income (Rupiah) & Frequency (N) & Percent (\%) \\
\hline & & & \\
\hline 1. & $<$ 1 million & 13 & 21,7 \\
2. & 1 million s/d 2 million & 23 & 38,3 \\
3. & 2 million s/d 4 million & 15 & 25 \\
4. & 4 million s/d 7 million & 5 & 8,3 \\
5. & $>7$ million & 4 & 6,7 \\
\hline & Total & $\mathbf{6 0}$ & $\mathbf{1 0 0}$ \\
\hline
\end{tabular}

Table 6. Amount of Respondents Based on Marriage Status

\begin{tabular}{|c|c|c|c|}
\hline Number. & Married Status & Frequency $(\mathbf{N})$ & Percent $(\%)$ \\
\hline 1. & Single & 23 & 38,3 \\
\hline 2. & Married & 37 & 61,7 \\
\hline \multicolumn{2}{|c|}{ Total } & 60 & 100 \\
\hline
\end{tabular}

Table 7. Amount of Respondents Based on the Amount of Family Members Who Live at Home

\begin{tabular}{llcc}
\hline Number. & Number of Family Members at Home & Frequency (N) & Percent (\%) \\
\hline & & & \\
\hline 1. & 2 Persons & 14 & 23,3 \\
2. & 3 Persons & 21 & 35 \\
3. & 4 Persons & 12 & 20 \\
4. & > 4 Persons & 13 & 21,7 \\
\hline & Total & $\mathbf{6 0}$ & $\mathbf{1 0 0}$ \\
\hline
\end{tabular}

Table 8. Amount of Respondents Based on Home Ownership Status

\begin{tabular}{llcc}
\hline Number. & Home Ownership Status & Frequency (N) & Percent (\%) \\
\hline & & & \\
\hline 1. & One's own & 21 & 35 \\
2. & Family owned & 16 & 26,7 \\
3. & Rent & 20 & 33,3 \\
4. & Others & 3 & 5 \\
\hline & Total & $\mathbf{6 0}$ & $\mathbf{1 0 0}$ \\
\hline
\end{tabular}

Table 9. Amount of Respondents Based on Electricity 


\begin{tabular}{llcc}
\hline Number. & Electricity (in watts) & Frequency (N) & Percent (\%) \\
\hline & & & \\
\hline 1. & 450 & 41 & 68,3 \\
2. & 900 & 12 & 20 \\
3. & 1200 & 4 & 6,7 \\
4. & 2200 & 3 & 5 \\
\hline & Total & $\mathbf{6 0}$ & $\mathbf{1 0 0}$ \\
\hline
\end{tabular}

Table 10. Amount of Respondents Based on Average Payments Accounts Electricity a month

\begin{tabular}{llcc}
\hline Number. & Average Payment Electricity Account (Rupiah) & Frequency (N) & Percent (\%) \\
\hline & & & \\
\hline 1. & $<50$ thousand & 4 & 6,7 \\
2. & 50 thousand s/d 100 thousand & 48 & 80 \\
3. & 100 thousand s/d 300 thousand & 6 & 10 \\
4. & 300 thousand s/d 1 million & 2 & 3,3 \\
\hline & Total & $\mathbf{6 0}$ & $\mathbf{1 0 0}$ \\
\hline
\end{tabular}

Table 11. Amount of Respondents Based on Place Counters Paying Electricity Accounts

\begin{tabular}{llcc}
\hline Number. & Counters often pay electricity accounts & Frequency (N) & Percent (\%) \\
\hline & & & \\
\hline 1. & Bank / Post Office & 8 & 13,3 \\
2. & PPOB Counters & 50 & 83,3 \\
3. & Others & 2 & 3,3 \\
\hline & Total & $\mathbf{6 0}$ & $\mathbf{1 0 0}$ \\
\hline
\end{tabular}

\subsection{Description of Research Variable Characteristics}

This research consists of 5 independent variables, and 1 variable dependent. Independent variable is $\mathrm{X}$ variable (service quality or service quality) which consists of five variable dimensions, namely physical evidence variable $\left(\mathrm{X}_{1}\right)$, reliability variable $\left(\mathrm{X}_{2}\right)$, responsiveness variable $\left(\mathrm{X}_{3}\right)$, guarantee variable $\left(\mathrm{X}_{4}\right)$, and empathy variable $\left(\mathrm{X}_{5}\right)$ The dependent variable is variable $\mathrm{Y}$ is the decision to pay.

Infornation: Strongly Disagree (SD), Disagree (D), Less Agree (LA), Agree (A), Strongly Agree (SA)

Table 12. Score of Variable Physical Evidence (X1)

\begin{tabular}{|c|c|c|c|c|c|c|c|c|c|c|c|}
\hline & \multirow{3}{*}{ Indicator } & \multicolumn{10}{|c|}{ Score } \\
\hline & & \multicolumn{2}{|c|}{1 (SD) } & \multicolumn{2}{|c|}{2 (D) } & \multicolumn{2}{|c|}{3 (LA) } & \multicolumn{2}{|c|}{$4(A)$} & \multicolumn{2}{|c|}{5 (SA) } \\
\hline & & $\mathbf{N}$ & $\%$ & $\mathbf{N}$ & $\%$ & $\mathbf{N}$ & $\%$ & $\mathbf{N}$ & $\%$ & $\mathbf{N}$ & $\%$ \\
\hline $\mathrm{X}_{11}$ & Modern appearance & - & - & 1 & 1,7 & 19 & 31,7 & 34 & 56,7 & 6 & 10 \\
\hline $\mathrm{X}_{12}$ & Visually Attract & - & - & - & - & 15 & 25 & 25 & 41,7 & 20 & 33,3 \\
\hline $\mathrm{X}_{13}$ & Neat-looking employees & - & - & 2 & 3,3 & 22 & 36,7 & 31 & 51,7 & 5 & 8,3 \\
\hline $\mathrm{X}_{14}$ & Visually interesting material & 3 & 5 & 7 & 11,7 & 23 & 38,3 & 27 & 45 & - & - \\
\hline
\end{tabular}

Table 13. Score of Reliability Variables $\left(\mathbf{X}_{2}\right)$

\begin{tabular}{|c|c|c|c|c|c|c|c|c|c|c|c|}
\hline & \multirow{3}{*}{ Indicator } & \multicolumn{10}{|c|}{ Score } \\
\hline & & \multicolumn{2}{|c|}{1 (SD) } & \multicolumn{2}{|c|}{2 (D) } & \multicolumn{2}{|c|}{3 (LA) } & \multicolumn{2}{|c|}{$4(A)$} & \multicolumn{2}{|c|}{5 (SA) } \\
\hline & & $\mathbf{N}$ & $\%$ & $\mathbf{N}$ & $\%$ & $\mathbf{N}$ & $\%$ & $\mathbf{N}$ & $\%$ & $\mathbf{N}$ & $\%$ \\
\hline $\mathrm{X}_{21}$ & Janji yang ditepati & 3 & 5 & 7 & 11,7 & 23 & 38,3 & 27 & 45 & - & - \\
\hline $\mathrm{X}_{22}$ & $\begin{array}{l}\text { Bantuan perusahaan dengan } \\
\text { sungguh }\end{array}$ & 2 & 3,3 & 11 & 18,3 & 30 & 50 & 17 & 28,3 & - & - \\
\hline $\mathrm{X}_{23}$ & Layanan tepat sejak awal & 5 & 8,3 & 12 & 20 & 28 & 46,7 & 14 & 23,3 & 1 & 1,7 \\
\hline $\mathrm{X}_{24}$ & $\begin{array}{l}\text { Layanan diberikan sesuai } \\
\text { dengan waktu dijanjikan }\end{array}$ & 5 & 8,3 & 5 & 8,3 & 34 & 56,7 & 15 & 25 & 1 & 1,7 \\
\hline $\mathrm{X}_{25}$ & Catatan bebas dari kesalahan & 2 & 3,3 & 9 & 15 & 27 & 45 & 19 & 31,7 & 3 & 5 \\
\hline
\end{tabular}

Table 14. Variable Responsiveness $\left(X_{3}\right)$ 


\begin{tabular}{|c|c|c|c|c|c|c|c|c|c|c|c|}
\hline & & \multicolumn{2}{|c|}{1 (SD) } & \multicolumn{2}{|c|}{2 (D) } & \multicolumn{2}{|c|}{3 (LA) } & \multicolumn{2}{|c|}{$4(A)$} & \multicolumn{2}{|c|}{5 (SA) } \\
\hline & & $\mathbf{N}$ & $\%$ & $\mathbf{N}$ & $\%$ & $\mathbf{N}$ & $\%$ & $\mathbf{N}$ & $\%$ & $\mathbf{N}$ & $\%$ \\
\hline $\mathrm{X}_{31}$ & $\begin{array}{l}\text { Memberitahu pelanggan kapan } \\
\text { saja disampaikan }\end{array}$ & 1 & 1,7 & 2 & 3,3 & 31 & 51,7 & 24 & 40 & 2 & 3,3 \\
\hline$X_{32}$ & $\begin{array}{l}\text { Memberikan pelayanan yang } \\
\text { cepat }\end{array}$ & - & - & 4 & 6,7 & 24 & 40 & 31 & 51,7 & 1 & 1,7 \\
\hline $\mathrm{X}_{33}$ & $\begin{array}{l}\text { Selalu bersedia membantu } \\
\text { pelanggan }\end{array}$ & - & - & 1 & 1,7 & 32 & 53,3 & 26 & 43,3 & 1 & 1,7 \\
\hline $\mathrm{X}_{34}$ & $\begin{array}{l}\text { Tidak pernah terlalu sibuk } \\
\text { merespon permintaan pelanggan }\end{array}$ & - & - & - & - & 26 & 43,3 & 28 & 46,7 & 6 & 10 \\
\hline
\end{tabular}

Table 15. Guarantee Variable Score $\left(\mathbf{X}_{4}\right)$

\begin{tabular}{|c|c|c|c|c|c|c|c|c|c|c|c|}
\hline & \multirow{3}{*}{ Indicator } & \multicolumn{10}{|c|}{ Skor } \\
\hline & & \multicolumn{2}{|c|}{1 (SD) } & \multicolumn{2}{|c|}{2 (D) } & \multicolumn{2}{|c|}{3 (LA) } & \multicolumn{2}{|c|}{$4(A)$} & \multicolumn{2}{|c|}{5 (SA) } \\
\hline & & $\mathbf{N}$ & $\%$ & $\mathbf{N}$ & $\%$ & $\mathbf{N}$ & $\%$ & $\mathbf{N}$ & $\%$ & $\mathbf{N}$ & $\%$ \\
\hline $\mathrm{X}_{41}$ & $\begin{array}{l}\text { Perilaku karyawan membuat } \\
\text { pelanggan mempercayai }\end{array}$ & - & - & - & - & 17 & 28,3 & 20 & 33,3 & 23 & 38,3 \\
\hline $\mathrm{X}_{42}$ & $\begin{array}{l}\text { Pelanggan merasa aman } \\
\text { bertransaksi }\end{array}$ & - & - & - & - & 17 & 28,3 & 21 & 35 & 22 & 36,7 \\
\hline $\mathrm{X}_{43}$ & Konsisten bersikap sopan & 2 & 3,3 & 5 & 8,3 & 20 & 33,3 & 15 & 25 & 18 & 30 \\
\hline $\mathrm{X}_{44}$ & $\begin{array}{l}\text { Memiliki pengetahuan memadai } \\
\text { menjawab pertanyaan pelanggan }\end{array}$ & 1 & 1,7 & 1 & 1,7 & 26 & 43,3 & 19 & 31,7 & 13 & 21,7 \\
\hline
\end{tabular}

Table 16. Score of Empathy Variables $\left(X_{5}\right)$

\begin{tabular}{|c|c|c|c|c|c|c|c|c|c|c|c|}
\hline & \multirow{3}{*}{ Indicator } & \multicolumn{10}{|c|}{ Skor } \\
\hline & & \multicolumn{2}{|c|}{1 (SD) } & \multicolumn{2}{|c|}{2 (D) } & \multicolumn{2}{|c|}{3 (LA) } & \multicolumn{2}{|c|}{$4(A)$} & \multicolumn{2}{|c|}{$5(\mathbf{S A})$} \\
\hline & & $\mathbf{N}$ & $\%$ & $\mathbf{N}$ & $\%$ & $\mathbf{N}$ & $\%$ & $\mathbf{N}$ & $\%$ & $\mathbf{N}$ & $\%$ \\
\hline $\mathrm{X}_{51}$ & $\begin{array}{l}\text { Memberikan kenyamanan terhadap } \\
\text { pelanggan }\end{array}$ & 1 & 1,7 & 4 & 6,7 & 38 & 63,3 & 16 & 26,7 & 1 & 1,7 \\
\hline$X_{52}$ & Memilki jam operasi yang nyaman & 1 & 1,7 & 2 & 3,3 & 35 & 58,3 & 19 & 31,7 & 3 & 5 \\
\hline $\mathrm{X}_{53}$ & $\begin{array}{l}\text { Memiliki karyawan yang member } \\
\text { perhatian pribadi kepada } \\
\text { pelanggan }\end{array}$ & 2 & 3,3 & 6 & 10 & 33 & 55 & 18 & 30 & 1 & 1,7 \\
\hline$X_{54}$ & Selalu mengutamakan pelanggan & - & - & 2 & 3,3 & 29 & 48,3 & 16 & 26,7 & 13 & 21,7 \\
\hline$X_{55}$ & $\begin{array}{l}\text { Memahami kebutuhan spesifik } \\
\text { pelanggan }\end{array}$ & 1 & 1,7 & 3 & 5 & 27 & 45 & 13 & 21,7 & 16 & 26,7 \\
\hline
\end{tabular}

Table 17. Score Decision Variables for Paying (Y)

\begin{tabular}{|c|c|c|c|c|c|c|c|c|c|c|c|}
\hline & \multirow{3}{*}{ Indikator } & \multicolumn{10}{|c|}{ Skor } \\
\hline & & \multicolumn{2}{|c|}{1 (SD) } & \multicolumn{2}{|c|}{$2(\mathrm{D})$} & \multicolumn{2}{|c|}{$3(\mathrm{LA})$} & \multicolumn{2}{|c|}{$4(A)$} & \multicolumn{2}{|c|}{5 (SA) } \\
\hline & & $\mathbf{N}$ & $\%$ & $\mathbf{N}$ & $\%$ & $\mathbf{N}$ & $\%$ & $\mathbf{N}$ & $\%$ & $\mathbf{N}$ & $\%$ \\
\hline $\mathrm{Y}_{11}$ & $\begin{array}{l}\text { Konsumen membayar tagihan di } \\
\text { loket pembayaran }\end{array}$ & 1 & 1,7 & 3 & 5 & 37 & 61,7 & 18 & 30 & 1 & 1,7 \\
\hline$Y_{12}$ & $\begin{array}{l}\text { Konsumen kembali membayar } \\
\text { tagihan di loket pembayaran }\end{array}$ & 1 & 1,7 & 3 & 5 & 37 & 61,7 & 19 & 31,7 & - & - \\
\hline$Y_{13}$ & $\begin{array}{l}\text { Konsumen merasa puas membayar } \\
\text { di loket pembayaran }\end{array}$ & - & - & 2 & 3,3 & 39 & 65 & 17 & 28,3 & 2 & 3,3 \\
\hline$Y_{14}$ & $\begin{array}{l}\text { Konsumen merasa senang dan } \\
\text { nyaman membayar di loket } \\
\text { pembayaran }\end{array}$ & - & - & 2 & 3,3 & 37 & 61,7 & 18 & 30 & 3 & 5 \\
\hline
\end{tabular}

\subsection{Analisis Statistik}

Table 18 Instrument Validity Test Results

\begin{tabular}{cccc}
\hline Variable & Item & R & Information \\
\hline Bukti Fisik $\left(\mathbf{X}_{\mathbf{1}}\right)$ & $\mathrm{X}_{1.1}$ & 0,887 & Valid \\
& $\mathrm{X}_{1.2}$ & 0,868 & Valid \\
& $\mathrm{X}_{1.3}$ & 0,823 & Valid \\
& $\mathrm{X}_{1.4}$ & 0,765 & Valid \\
\hline Keandalan & $\mathrm{X}_{2.1}$ & 0,783 & Valid \\
\hline
\end{tabular}




\begin{tabular}{cccc}
\hline$\left(\mathbf{X}_{\mathbf{2}}\right)$ & $\mathrm{X}_{2.2}$ & 0,716 & Valid \\
& $\mathrm{X}_{2.3}$ & 0,757 & Valid \\
& $\mathrm{X}_{2.4}$ & 0,715 & Valid \\
& $\mathrm{X}_{2.5}$ & 0,745 & Valid \\
\hline Daya Tanggap & $\mathrm{X}_{3.1}$ & 0,827 & Valid \\
$\left(\mathbf{X}_{\mathbf{3}}\right)$ & $\mathrm{X}_{3.2}$ & 0,895 & Valid \\
& $\mathrm{X}_{3.3}$ & 0,871 & Valid \\
\hline Jaminan & $\mathrm{X}_{3.4}$ & 0,638 & Valid \\
\hline $\left.\mathbf{X}_{\mathbf{4}}\right)$ & $\mathrm{X}_{4.1}$ & 0,893 & Valid \\
& $\mathrm{X}_{4.2}$ & 0,885 & Valid \\
& $\mathrm{X}_{4.3}$ & 0,861 & Valid \\
\hline Empati & $\mathrm{X}_{4.4}$ & 0,726 & Valid \\
\hline $\left.\mathbf{X}_{\mathbf{5}}\right)$ & $\mathrm{X}_{5.1}$ & 0,517 & Valid \\
& $\mathrm{X}_{5.2}$ & 0,687 & Valid \\
& $\mathrm{X}_{5.3}$ & 0,644 & Valid \\
& $\mathrm{X}_{5.4}$ & 0,797 & Valid \\
& $\mathrm{X}_{5.5}$ & 0,613 & Valid \\
\hline Keputusan Membayar $(\mathbf{Y})$ & $\mathrm{Y}_{1.1}$ & 0,889 & Valid \\
& $\mathrm{Y}_{1.2}$ & 0,828 & Valid \\
& $\mathrm{Y}_{1.3}$ & 0,648 & Valid \\
& $\mathrm{Y}_{1.4}$ & 0,762 & Valid \\
\hline
\end{tabular}

Table 19. Instrument Reliability Test Results

\begin{tabular}{ccc}
\hline Variabel & Cronbach's Alpha & Information \\
\hline X1 (Bukti Fisik) & 0,855 & Reliable \\
\hline X2 (Keandalan) & 0,797 & Reliable \\
\hline X3 (Daya Tanggap) & 0,817 & Reliable \\
\hline X4 (Jaminan) & 0,854 & Reliable \\
\hline X5 (Empati) & 0,657 & Reliable \\
\hline Y (Keputusan Membayar) & 0,791 & Reliable \\
\hline
\end{tabular}

\subsubsection{Classical Assumption Test Results}

\section{a. Multicollinearity Test}

Multicollinearity test aims to test whether the regression model found correlation between independent variables. A good regression model should not have correlation between independent variables (Ghozali, 2009).

Table 20. Multicollinearity Test

\begin{tabular}{ccc}
\hline Variable & VIF & Information \\
\hline X1 & 1,741 & Non multikolinieritas \\
X2 & 1,167 & Non multikolinieritas \\
X3 & 1,294 & Non multikolinieritas \\
X4 & 1,849 & Non multikolinieritas \\
X5 & 1,576 & Non multikolinieritas \\
\hline
\end{tabular}

A statistical analysis said that there were no symptoms of multicollinearity, if the value of VIF (Variance Inflation Factor) $<10$ (Ghozali, 2009). The results of the calculations are shown in Table 20, where the VIF values for all independent variables are $\mathrm{X}(\mathrm{X} 1, \mathrm{X} 2, \mathrm{X} 3, \mathrm{X} 4$, and X5) less than $10(<10)$. So it can be concluded that there are no symptoms of multicollinearity in this research model.

\section{b. Heteroscedasticity Test}

Image 1. Scatterplot Graph for Heteroscedasticity Test 


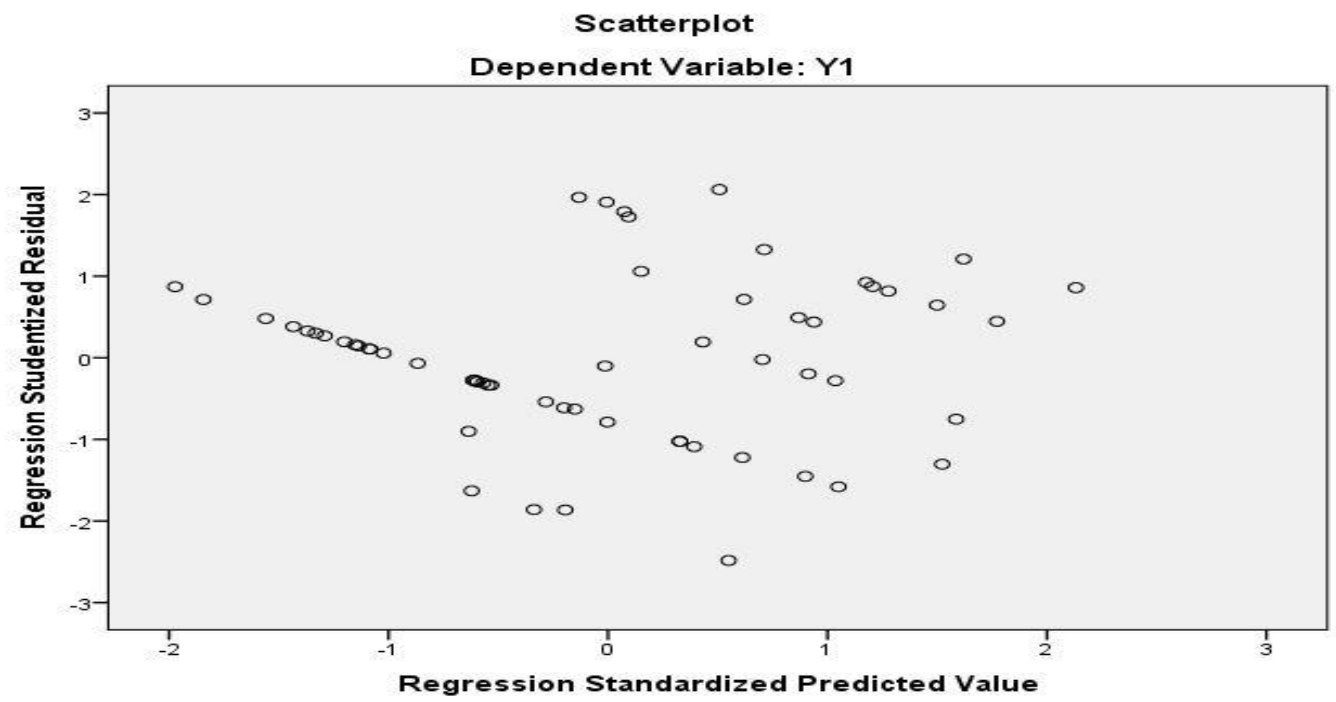

In image 1 , it can be seen that the points spread randomly both above and below the number 0 on the $\mathrm{Y}$ axis. This can be disensus which does not occur heteroscedasticity. In addition, there are no patterns formed in other words plot graphs.

\section{c. Normality test}

Normality test aims to test whether in the regression model, confounding variables, or residuals have a normal distribution (Ghozali, 2009). To see normality in the regression model can be seen in image 2.

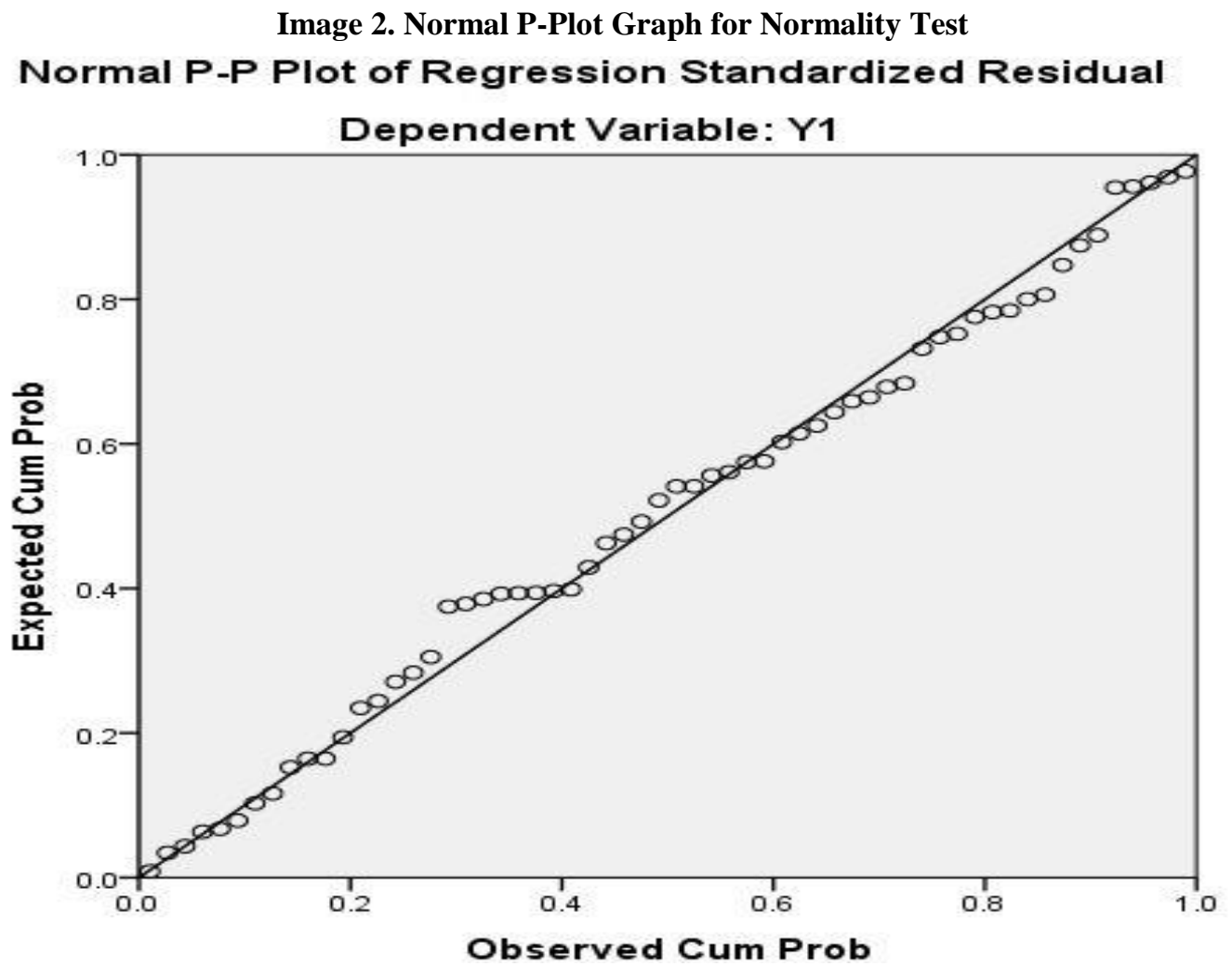

Image 2, shows that the Normal P-P graph plot of regression standardized residuals, describes the distribution of data around the diagonal line, and its distribution follows the direction of the diagonal line of the graph, then the regression model used in this research, fulfills the assumption of normality.

\subsubsection{Results of Multiple Linear Regression Analysis}

a. Test F

To determine the effect of independent variables together on the dependent variable, the $F$ test is used. If the value of $F<F_{1-}$ $\alpha,(\mathrm{k}, \mathrm{n}-\mathrm{k}-1)$, or $\mathrm{p}>0.05$ then $\mathrm{H} 0$ is accepted and $\mathrm{Ha}$ is rejected. The opposite is true.

b. Test $\mathrm{t}$

To determine the effect of partially independent variables on the dependent variable, $t$ test is used. If value $t<t_{1-\alpha,(n-2)}$ or p>0,05 then $\mathrm{H} 0$ is accepted by Ha rejected. The results of multiple regression tests are shown in Table 21. 
Table 21. Statistics of Multiple Linear Regression Tests

\begin{tabular}{|c|c|c|c|c|c|c|}
\hline Variable & & B & Std Error & $\mathbf{T}$ & Sig t & Information \\
\hline Constants & & 2,754 & 1,855 & 1,485 & 0,000 & \\
\hline X1 (Physical evidence) & & 0,030 & 0,118 & 0,258 & 0,000 & Significant \\
\hline X2 (Reliability) & & 0,126 & 0,071 & 1,774 & 0,002 & Significant \\
\hline X3 (Responsiveness) & & 0,234 & 0,115 & 2,029 & 0,000 & Significant \\
\hline X4 (Guarantee) & & 0,080 & 0,094 & 0,853 & 0,007 & Significant \\
\hline X5 (Empathy) & & 0,204 & 0,101 & 2,027 & 0,001 & Significant \\
\hline $\mathrm{R}$ & $=0,624$ & & & $\mathrm{n}=60$ & & \\
\hline R Square & $=0,389$ & & & $\alpha=5 \%$ & 05) & \\
\hline Adjusted R Square & $=0,333$ & & & & & \\
\hline $\mathrm{F}_{\text {count }}$ & $=6,878$ & & & & & \\
\hline Sig F & $=0,000$ & & & & & \\
\hline
\end{tabular}

Table 21 above can be concluded that:

a. The Fcount value shows a value of 6.878 (significance of $F=0,000$ ). This means that together there are differences in the effect of variable $\mathrm{X}$ on variable $\mathrm{Y}$. Thus, the hypothesis that mentions together the variable $\mathrm{X}$, has a different effect on the variable $\mathrm{Y}$ is accepted, or proven.

b. From the $\mathrm{R}$ square value shows the value of 0.389 , or $38.9 \%$. This means that variable $\mathrm{Y}$ is affected by $38.9 \%$ by Variable $\mathrm{X}$, while $61.1 \%$ is influenced by other variables, outside of the 5 independent variables studied.

c. Regression equation:

$$
\mathrm{Y}=2,754+0,030 \mathrm{X}_{1}+0,126 \mathrm{X}_{2}+0,234 \mathrm{X}_{3}+0,080 \mathrm{X}_{4}+0,204 \mathrm{X}_{5}+\mathrm{e}
$$

d. The value of $\alpha$ constant is 2.754 where the value means, that if the physical evidence, reliability, responsiveness, assurance, and empathy variables do not exist, or zero, then the decision to pay, namely paying electricity bills at the PPOB counter is 2,754 .

e. Variable X1 is physical evidence, with a regression coefficient of 0.030 , and a tcount of 0.258 , with a probability of $0.000(<0.05)$. Where, every addition, or an increase of +1 of physical evidence, increases the decision to pay electricity bills of $0.030(3 \%)$. Partially variable $\mathrm{X} 1$, has a significant positive effect on variable $\mathrm{Y}$, if other independent variables remain in value. Thus, the hypothesis that there is a significant effect of physical evidence variables on the variable decision to pay is accepted.

f. X2 variable reliability, with a regression coefficient of 0.126 , and a tcount of 1.774 , with a probability of $0.002(<0.05)$. Where, each addition, or an increase of +1 reliability variable, increases the electricity bill payment decision by 0.126 (12.6\%). Partially, variable X2 has a significant positive effect on variable $\mathrm{Y}$, if other independent variables remain in value. Thus, the hypothesis that there is a significant effect of reliability, on the decision to pay is accepted.

g. The X3 variable is responsive, with a regression coefficient of 0.234 , and a tcount of 2.029 with a probability of 0.000 $(<0.05)$. Where, each addition, or an increase of +1 of the responsiveness variable, increases the electricity bill payment decision by $0.234(23.4 \%)$. Partially variable $\mathrm{X} 3$, has a significant positive effect on variable $\mathrm{Y}$ if other independent variables remain in value. Thus, the hypothesis that there is a significant effect of responsiveness on the decision to pay is accepted.

h. Variable X4 guarantees, with a regression coefficient of 0.080 , and a tcount of 0.853 with a probability of 0.007 ( $<0.05)$. Where, each addition, or an increase of +1 guarantee variable increases the decision to pay electricity bills of 0.080 ( $8 \%$ ). Partially variable X4 has a significant positive effect on variable Y, if other independent variables remain in value. Thus, the hypothesis that there is a significant effect of collateral, on the decision to pay is accepted

i. Variable X5 is empathy, with a regression coefficient of 0.204 , and a tcount of 2.027 with a probability of $0.001(<0.05)$. Where, every addition, or an increase of +1 from the empathy variable increases electricity bill payout decisions by 0.204 (20.4\%). Partially variable X5, has a significant positive effect on variable Y, if other independent variables remain in value. Thus, the hypothesis that there is a significant influence of empathy on the decision to pay is accepted.

\section{Effect of Physical Evidence on Paying Decisions}

Based on the results of multiple regression analysis, it was found that physical evidence variables, have a positive influence, and are significant to the decision to pay electricity bills. The relationship between physical evidence of payment decisions, in this study shows positive, and significant results (0.030, and 0.000). These results indicate that the hypothesis that states, physical evidence variables have a partial effect on the decision to pay electricity bills, are accepted or proven. This can be seen from the results of the $t$ test, for the decision to pay gives the result of a p-value, or a significance of 0.000 , or $<0.05$ this indicates that there is a significant influence of physical evidence on the decision to pay electricity bills. The results of the regression analysis show that the value of the physical evidence variable is 0.030 , or $3 \%$, where each increase of +1 of physical evidence will increase the decision to pay 0.030 , or $3 \%$. This result is low, and becomes the lowest compared to the other dimensions of service quality in this research.

\section{Effect of Reliability on Decision to Pay}

Based on the results of multiple regression analysis, it was found that the reliability variable had a positive influence, and was significant on the decision to pay electricity bills at PPOB Manado. The relationship between reliability and payment decisions in this study showed positive and significant results $(0.126$ and 0.002$)$. These results indicate that the hypothesis which 
states that the reliability variable has a partial effect on the decision to pay electricity bills is accepted, or proven. This can be seen from the results of the $t$ test, for the decision to pay gives the results of $\mathrm{p}$-value, or a significance of 0.002 , or $<0.05$, this indicates that there is a significant effect of reliability on the decision to pay electricity bills. The results of the regression analysis show that the value of the reliability variable is 0.126 , or $12.6 \%$, where every increase of +1 of reliability will increase the pay decision, by 0.126 or $12.6 \%$. These results indicate that the hypothesis which states that the reliability variable is partially influential on the decision to pay electricity bills at the Manado PPOB counter is accepted, or proven.

\section{The Effect of Responding on Decisions to Pay}

Based on the results of multiple regression analysis, it was found that the responsiveness variable has a positive influence, and is significant on the decision to pay electricity bills at PPOB Manado. The relationship between responsiveness to the decision to pay in this study, showed positive results, and significant $(0.234$, and 0.000$)$. These results indicate that the hypothesis states that responsiveness variables have a partial effect on the decision to pay electricity bills, are accepted, or proven. This can be seen from the results of the t test for the decision to pay giving the results of the p-value, or a significance of 0.000 or $<0.05$, this indicates that there is a significant influence from the responsiveness to the decision to pay electricity bills. The results of regression analysis show that the value of the responsiveness variable is 0.234 , or $23.4 \%$, where every increase of +1 of responsiveness, will increase the decision to pay 0.234 , or $23.4 \%$. These results indicate that the hypothesis which states that responsiveness variables partially affect the decision to pay electricity bills is accepted or proven.

\section{The effect of collateral on the decision to pay}

Based on the results of multiple regression analysis, it was found that the guarantee variable has a positive influence, and is significant on the decision to pay electricity bills. The relationship between collateral and payment decisions, in this study showed positive and significant results $(0.080$ and 0.007$)$. These results indicate that the hypothesis which states that the guarantee variable has a partial effect on the decision to pay electricity bills, is accepted, or proven. This can be seen from the results of the $t$ test for the decision to pay giving the results of the p-value, or a significance of 0.007 , or $<0.05$. The results of regression analysis show that the variable value of the guarantee is equal to 0.080 or by $8 \%$, where each increase of +1 of the guarantee will increase the decision to pay by 0.080 or $8 \%$. These results indicate that the hypothesis states that the guarantee variable partially affects the decision to pay electricity bills accepted or proven.

\section{Effect of Empathy on Decision to Pay}

Based on the results of multiple regression analysis, it was found that empathy variables, have a positive influence, and are significant in the decision to pay electricity bills. The relationship between empathy for paying decisions in this study shows positive, and significant results $(0.204$, and 0.001$)$. These results indicate that the hypothesis which states that the empathy variable has a partial effect on the decision to pay the electricity account $\mathrm{F}$ is accepted, or proven. This can be seen from the results of the $t$ test for paying decisions giving the results of the p-value, or a significance of 0.001 , or $<0.05$, this indicates a significant influence of empathy on the decision to pay electricity bills. The results of regression analysis show that the value of the empathy variable is 0.204 , or $20.4 \%$, where each increase of +1 of empathy will increase the decision to pay by 0.204 or $20.4 \%$. These results indicate that the hypothesis which states that the empathy variable partially affects the decision to pay electricity bills is accepted or proven.

\section{Effect of Physical Evidence, Reliability, Responsiveness, Assurance, and Empathy on Decision to Pay}

Based on the results of the F test, it was found that the dimensions of service quality variables consisting of physical evidence variables, reliability variables, responsiveness variables, assurance variables, and empathy variables, together, or simultaneously have different effects on the decision to pay electricity bills at the PPOB Manado counter. The effect of these independent variables simultaneously on the pay decision in this study shows positive and significant results $(\mathrm{F}=6.878$, and Sig $\mathrm{F}$ $=0.000)$. These results indicate that the hypothesis which states that simultaneously, or together dimensions of service quality variables consisting of physical evidence variables, reliability variables, responsiveness variables, assurance variables, and empathy variables have different effects on the decision to pay electricity bills, accepted or proven.

\section{CONCLUSION}

The conclusion of this study is based on the findings, and discussion of research, namely:

1. The dimensions of service quality in the form of physical evidence variables, which consist of indicators: modern appearance, visually appealing, neat-looking employees, and visually appealing materials, have proven to have a positive influence on the decision to pay consumer electricity bills at PPOB in Manado

2. The reliability dimension, which consists of indicators: promises kept, company assistance with real, service, right from the start, services provided according to the promised time, as well as error-free records, proved to have a positive influence on the decision to pay electricity bills.

3. The responsiveness dimension, which consists of indicators: telling customers, when services will be delivered, providing fast service, always willing to help, never too busy, has proven to have a positive influence on the decision to pay electricity bills.

4. Guarantee dimension, which consists of: employee behavior, making customers trust, customers feel safe transacting, consistently being polite, and having adequate knowledge to answer customer questions, proven to have a positive influence on the decision to pay electricity bills.

5. The empathy dimension, which consists of indicators, providing convenience to customers, having comfortable operating hours, having employees who give personal attention, always prioritizing the interests of customers, understanding the specific needs of customers, proved to have the greatest influence on the decision to pay electricity bills. This can be seen in the table of classical assumption test results, and multiple linear analysis in the table of coefficients, where the standardized coefficients in beta are $27 \%$. 
6. Simultaneously or together, the dimensions of service quality which consist of direct evidence, reliability, responsiveness, assurance, and empathy have different effects on the decision to pay consumer electricity bills at PPOB in Manado.

\section{REFERENCES}

Arikunto, S. 2010. Prosedur Penelitian: Suatu Pendekatan Praktik. Bandung: Rineka Cipta.

Assauri, S. 2004. Manajemen Pemasaran: Dasar, Konsep, dan Strategi. Jakarta: Rajawali Press.

Assegaff, M. 2009. Pengaruh Kualitas Pelayanan terhadap Kepuasan Pelanggan (Studi pada Perusahaan Penerbangan PT. Garuda Di Kota Semarang). Jurnal Ekonomi dan Bisnis. Vol. 10. No. 2. Juli. Hal. 171 - 186. Unisulla Semarang. Semarang.

Atmawati, R. dan Wahyuddin. 2007. Analisis Pengaruh Kualitas Pelayanan terhadap Kepuasan Konsumen pada Matahari Departement Store di Solo Grand Mall. Jurnal Ekonomi dan Bisnis. Hal. 1 - 12. Universitas Muhammadiyah Surakarta. Surakarta.

Azwar, S. 2000. Reliabilitas dan Validitas. Yogyakarta: Pustaka Pelajar.

Chandra, G. 2001. Strategi dan Program Pemasaran, Yogyakarta: Penerbit Andi.

Ghozali, I. 2009. Aplikasi Analisis Multivariate dengan Program SPSS. Semarang: Badan Penerbit Universitas Diponegoro.

Hawkins, D. I., Best, R. J., and K. A. Coney. 2001. Consumer Behavior: Building Marketing Strategy”, Eight Edition, New York: McGraw-Hill.

Jonathan, R. 2005. Pengaruh Kualitas Pelayanan terhadap Kepuasan Pelanggan pada Sektor Publik di Kabupaten dan Kota di Propinsi Kalimantan Timur. Jurnal Keuangan dan Perbankan. Th. IX. No. 2, Mei. Universitas 17 Agustus 1945. Samarinda.

PT PLN (PERSERO) P3B JAWA BALI, 2010. Prosedur Teknik Statistik untuk Mengukur Kepuasan Pelanggan. Diakses Pada Maret 2012. http//www.google.com.

Solomon, M.1 R. 2002. Consumer Behavior: Buying, Having, and Being.Fifth Edition. New Jersey: Prentice-Hall, Inc.

Sugiyono. 2008. Metode Penelitian Kuantitatif, Kualitatif dan R\&D. Bandung: Alfabeta.

Waluyo, M. 2008. Pengaruh Kualitas Pelayanan terhadap Standard Pelayanan Terpadu dan Kepuasan Pelanggan di PT. PLN (Persero) UPJ X Surabaya. Jurnal Penelitian Ilmu Teknik. Vol 8. No. 2 Desember. 74-85.

Zeithaml, V. A., A.L. Berry. dan A. Parasuraman.1996. The Behavioral Consequences of Service Quality. Journal of Marketing. 60 (April). 